\title{
Mechanisms of the gold-catalysed water-gas shift
}

"If the trumpet sound an uncertain note, who shall obey the call?"

\section{Geoffrey Bond ${ }^{1}$}

www.goldbulletin.org

\begin{abstract}
Mechanisms proposed for the gold-catalysed Water-Gas Shift (WGS) are critically reviewed, and a complete reaction set and cycle involving activation of water on reduced support sites is considered; however, a modified route to $\mathrm{CO}_{2}$ formation by thermal decomposition of a carboxyl species results in a simpler and therefore more probable mechanism.
\end{abstract}

\section{Introduction}

The development of the industrial economy in the 19th Century required a source of a cheap and easily transportable energy form for heating, lighting and chemical processes. Passage of steam over a bed of coke, formed by carbonisation of coal, at red heat produced water-gas containing $\mathrm{H}_{2}, \mathrm{CO}$ and $\mathrm{CO}_{2}$ [1]. Chemical reactions such as $\mathrm{NH}_{3}$ synthesis and fat-hardening however need very pure $\mathrm{H}_{2}$, and while $\mathrm{CO}_{2}$ is easily absorbed by water the $\mathrm{CO}$ has to be removed by the WGS:

$$
\mathrm{CO}+\mathrm{H}_{2} \mathrm{O}=\mathrm{H}_{2}+\mathrm{CO}_{2}
$$

This is an endothermic reaction $\left(\Delta \mathrm{H}^{\circ}{ }_{298}=-41.2 \mathrm{~kJ}\right.$ $\mathrm{mol}^{-1}$ ), so that for high conversion an active catalyst is needed to work below about $473 \mathrm{~K}$. Currently on a large scale the reaction is conducted in two stages, the first at high temperature using an iron-chromium catalyst and the second at lower temperature with $\mathrm{CuZn} / \mathrm{Al}_{2} \mathrm{O}_{3}$ [1]. Interest in $\mathrm{H}_{2}$-powered fuel cells has led to efforts to use this reaction to lower the concentration of $\mathrm{CO}$ so as to avoid poisoning of the platinum electrodes, and early work $[1,2]$ demonstrated that gold on reducible supports $\left(\mathrm{CeO}_{2}, \mathrm{CeZrO}_{4}\right.$, and $\left.\mathrm{Fe}_{2} \mathrm{O}_{3}\right)$ was even more active than $\mathrm{CuZn} / \mathrm{Al}_{2} \mathrm{O}_{3}$ at low temperatures. This article examines certain of the proposals for a reaction mechanism, and makes suggestions for a simple version that is capable of experimental test.

\section{The redox mechanism}

Reaction mechanisms have been widely discussed $[1,2]$, and several basic forms have been considered. In the redox mechanism $\mathrm{CO}$ is oxidised by the support, which is thereby reduced, and is re-oxidised by water with the release of $\mathrm{H}_{2}$ : this mechanism has been summarised in the case of ceria $[3,4]$ as

$$
\begin{aligned}
& \mathrm{CO}+\mathrm{Au} \rightarrow \mathrm{CO}-\mathrm{Au} \\
& \mathrm{CO}-\mathrm{Au}+2 \mathrm{CeO}_{2} \rightarrow \mathrm{CO}_{2}+\mathrm{Ce}_{2} \mathrm{O}_{3}+\mathrm{Au} \\
& \mathrm{H}_{2} \mathrm{O}+\mathrm{Ce}_{2} \mathrm{O}_{3} \rightarrow \mathrm{CeO}_{2}+\mathrm{H}_{2}
\end{aligned}
$$


An alternative formulation assumes the existence of surface anion defects $\left(\square_{s}\right)$ upon which water is adsorbed before its dissociation [3], the reaction set then being

$$
\begin{aligned}
& \mathrm{CO}+\mathrm{Au} \rightarrow \mathrm{CO}-\mathrm{Au} \\
& \mathrm{H}_{2} \mathrm{O}+\square_{\mathrm{s}} \rightarrow \mathrm{H}_{2} \mathrm{O}_{\mathrm{s}} \\
& \mathrm{H}_{2} \mathrm{O}+\mathrm{Au} \rightarrow \mathrm{OH}_{\mathrm{s}}+\mathrm{H}-\mathrm{Au} \rightarrow \mathrm{O}_{\mathrm{s}}+\mathrm{H}_{2}+\mathrm{Au} \\
& \mathrm{CO}-\mathrm{Au}+\mathrm{O}_{\mathrm{s}} \rightarrow \mathrm{CO}_{2}+\square_{\mathrm{s}}+\mathrm{Au}
\end{aligned}
$$

the subscript $s$ standing for adsorption on the support. It is generally believed that the surfaces of effective supports are reduced at least partially [5] or perhaps even fully [6] by the two strongly reducing components of the water-gas system, but this requires the presence of gold [5] to chemisorb the $\mathrm{CO}$ or $\mathrm{H}_{2}$ [7]. Hydrogen spillover from metals is very well documented [8], and it is significant that the best supports contain cations the common oxidation states of which differ by one (i.e. $\mathrm{Ce}^{3+} / \mathrm{Ce}^{4+}, \mathrm{Fe}^{2+}$ / $\mathrm{Fe}^{3+}$ ). It was established long ago [9] that reduction of oxides by spill over $\mathrm{H}$ atoms is only rapid when this is the case, and it is the case also with $\mathrm{CO}$, the spillover of which was first demonstrated by comparing the activity of $\mathrm{Pd} / \mathrm{SnO}_{2}$ with that of $\mathrm{Pd} / \mathrm{SiO}_{2}$ for CO oxidation [10]. It is therefore not surprising to find that $\mathrm{ZnO}$ is a much worse support than $\mathrm{CeO}_{2}$ for the WGS [1]. There is a widespread feeling that anion vacancies play a vital role not only in the WGS, but also in CO oxidation where theyarethoughttoprovideameans of chemisorbing the $\mathrm{O}_{2}$ molecule as $\mathrm{O}_{2}^{-}[11,12]$.

\section{The formate mechanism}

The purely redox mechanism makes no allowance for $\mathrm{CH}_{\mathrm{x}} \mathrm{O}_{\mathrm{y}}$ intermediates such as bicarbonate, formate or carboxyl, for which there is extensive IR evidence [13]. The formate group $\left(\mathrm{HCO}_{2}\right)$ has often been cited as the likely reactive species, being formed on the support by reaction of a support $\mathrm{OH}$ with $\mathrm{CO}$ emanating from either the gas phase or a

Scheme I: Mechanisms of the Gold - Catalysed Water-Gas Shift: Scheme I

(A) $\mathrm{C} \equiv \mathrm{O}+\mathrm{H}-\mathrm{O} \rightarrow \stackrel{\mathrm{C}=\mathrm{O}}{\mathrm{O}} \rightarrow \mathrm{H}-\mathrm{C}^{\prime} \mathrm{O}$

(B) $\mathrm{C} \equiv \mathrm{O}+-\mathrm{O}-\mathrm{H} \rightarrow \underset{\mathrm{C}=\mathrm{O}}{\mathrm{O}} \rightarrow-\mathrm{C}^{\prime} \mathrm{O}$ gold particle [3].The latter seems more likely since it provides an otherwise lacking role for the metal. Wherever it is formed, making a $\mathrm{C}-\mathrm{H}$ bond requires the breaking of the $\mathrm{O}-\mathrm{H}$ bond, and the insertion of the $\mathrm{CO}$ molecule into it (see Scheme IA). To release $\mathrm{CO}_{2}$, the formate group may be oxidized by another $\mathrm{OH}$ species:

$$
\mathrm{HCO}_{2}+\mathrm{OH} \rightarrow \mathrm{CO}_{2}+\mathrm{H}_{2} \mathrm{O}
$$

The full reaction set for the formate mechanism is then written as

$$
\begin{aligned}
& \mathrm{CO}+\mathrm{Au} \rightarrow \mathrm{CO}-\mathrm{Au} \\
& \mathrm{H}_{2} \mathrm{O}+\square_{\mathrm{s}}+\mathrm{Au} \rightarrow \mathrm{OH}_{\mathrm{s}}+\mathrm{H}-\mathrm{Au} \\
& \mathrm{CO}-\mathrm{Au}+\mathrm{OH}_{\mathrm{s}} \rightarrow \mathrm{HCO}_{2}-\mathrm{Au}+\square_{\mathrm{s}} \\
& \mathrm{H}_{2} \mathrm{O}+\square_{\mathrm{s}}+\mathrm{Au} \rightarrow \mathrm{OH}_{\mathrm{s}}+\mathrm{H}-\mathrm{Au} \\
& \mathrm{HCO}_{2}-\mathrm{Au}+\mathrm{OH}_{\mathrm{s}} \rightarrow \mathrm{CO}_{2}+\mathrm{H}_{2} \mathrm{O}+\mathrm{Au}+\square_{\mathrm{s}} \\
& 2 \mathrm{H}-\mathrm{Au} \rightarrow \mathrm{H}_{2}+2 \mathrm{Au}
\end{aligned}
$$

The step describing the dissociation of the water molecule has to be repeated, because the $\mathrm{OH}_{\mathrm{s}}$ species is needed twice.

\section{The carboxyl mechanism}

The formate mechanism presents several difficulties that we will need to return to, but first we must note that there now appears to be increasing doubt that the formate species is indeed the essential intermediate. Quantitative DRIFTS has shown that only a minority of the $\mathrm{CO}_{2}$ is formed in this way $[14,15]$, and evidence is growing for the carboxyl group $(-\mathrm{COOH})$ as the preferred alternative. It was in fact proposed as the first step in $\mathrm{CO}$ oxidation on both reducible [12] and ceramic oxides [16], and DFT calculations show that it is the likely intermediate on $\mathrm{Au} / \mathrm{CeO}_{2}$ [17] and $\mathrm{Cu}(111)$ [18]. Bearing in mind the polarities of the reacting species, its formation has a greater chemical logic than that of the formate group (see Scheme IB).

The last reaction set can equally well be written with carboxyl in place of formate, and we now return to examine two possible difficulties. The first concerns the mechanism of decomposing the carboxyl (or formate) group. As written, it requires the activation of a second water molecule, the first being needed to form it. It seems illogical to include a process that results in creating a water molecule, when it is in fact a reactant. The alternative is that carboxyl simply decomposes to give $\mathrm{CO}_{2}$ and an $\mathrm{H}$-Au species, so 
that the reaction set is better represented as

$$
\begin{aligned}
& \mathrm{CO}+\mathrm{Au} \rightarrow \mathrm{CO}-\mathrm{Au} \\
& \mathrm{H}_{2} \mathrm{O}+\square_{\mathrm{s}}+\mathrm{Au} \rightarrow \mathrm{OH}_{\mathrm{s}}+\mathrm{H}-\mathrm{Au} \\
& \mathrm{CO}-\mathrm{Au}+\mathrm{OH}_{\mathrm{s}} \rightarrow \mathrm{HOOC}-\mathrm{Au}+\square_{\mathrm{s}} \\
& \mathrm{HOOC}-\mathrm{Au} \rightarrow \mathrm{CO}_{2}+\mathrm{H}-\mathrm{Au} \\
& 2 \mathrm{H}-\mathrm{Au} \rightarrow \mathrm{H}_{2}+2 \mathrm{Au}
\end{aligned}
$$

According to this simpler and more economical set, both $\mathrm{H}$ atoms of the product $\mathrm{H}_{2}$ molecule stem from the same water molecule, whereas with the more complex set they could come from two different molecules. That which occurs is susceptible of testing by the use of an $\mathrm{H}_{2} \mathrm{O}+\mathrm{D}_{2} \mathrm{O}$ mixture. This route to $\mathrm{CO}_{2}$ formation has also found favour in DFT calculations on $\mathrm{Au} / \mathrm{CeO}_{2}[17]$.

Thermal decomposition of the $\mathrm{Au}-\mathrm{COOH}$ species is reminiscent of the reaction of formic acid on metal catalysts, viz.

$$
\mathrm{HCOOH} \rightarrow \mathrm{CO}_{2}+\mathrm{H}_{2}
$$

This simple and easily monitored reaction was intensively studied in the 1950s and 1960s as a model to investigate the importance of electronic factors in catalysis by metals and alloys [19]. Supported gold catalysts $\left(\mathrm{Au} / \mathrm{SiO}_{2}, \mathrm{Au} / \mathrm{Al}_{2} \mathrm{O}_{3}\right)$ were found to be active between 373 and $573 \mathrm{~K}$ (see Table VII [19]), i.e. in the range where the catalysis of the WGS takes place. Activation energies were $\sim 65 \mathrm{~kJ} \mathrm{~mol}^{-1}$, and some of the values recorded for the shift reaction are in the range 45-55 $\mathrm{kJ} \mathrm{mol}^{-1}$ [1], i.e. considerably higher than typical values for CO oxidation ( $\left.\sim 30 \mathrm{~kJ} \mathrm{~mol}^{-1}\right)$. This reaction has long been neglected as being insufficiently photogenic, but it could be an easier method of scanning for WGS activity. The work performed on it reminds us that little work has been done using bimetallic catalysts of WGS; the success attending the use of palladium-gold catalysts for $\mathrm{H}_{2} \mathrm{O}_{2}$ synthesis [20] should be a powerful incentive for examining gold alloys.

\section{Activation of the water molecule}

Yet a further problem with the last reaction set concerns the manner of activating the water molecule. The process as written requires there to be an anion vacancy close to the edge of the gold particle, so that an $\mathrm{H}$ atom can jump directly onto it. While the support surface may be largely reduced [6] and the supply of anion vacancies plentiful, we must remember that each vacancy has been formed by the loss of an $\mathrm{O}^{2-}$ ion, and that two reduced support cations result, e.g.

$$
\mathrm{Ce}^{4+} \mathrm{O}^{2-} \mathrm{Ce}^{4+}+\mathrm{CO} \rightarrow \mathrm{CO}_{2}+\mathrm{Ce}^{3+} \square_{\mathrm{s}} \mathrm{Ce}^{3+}
$$

The adsorption of water on these reduced centres might then proceed first as [21]

$$
\mathrm{Ce}^{3+} \square_{\mathrm{s}} \mathrm{Ce}^{3+}+\mathrm{H}_{2} \mathrm{O} \rightarrow \mathrm{Ce}^{3+} \mathrm{OH}^{-} \mathrm{Ce}^{4+} \mathrm{H}
$$

before the $\mathrm{H}$ atom, migrating as necessary, makes its way to a gold particle. Possible evidence for such a step comes from the orders of reaction, which have been determined for reactants and products using an $\mathrm{Au} / \mathrm{CeO}_{2}-\mathrm{ZrO}_{2}$ catalyst at $433 \mathrm{~K}[1]$; they show

$$
\mathrm{r}=\mathrm{kP} \mathrm{C}_{\mathrm{CO}}{ }^{0.75} \mathrm{P}_{\mathrm{H}_{2} \mathrm{O}}{ }^{0.57} \mathrm{P}_{\mathrm{CO}_{2}}{ }^{-0.27} \mathrm{P}_{\mathrm{H}_{2}}{ }^{-0.99}
$$

While the positive orders for the reactants are not unexpected, the negative order for $\mathrm{CO}_{2}$ implies that it may have a chemisorbed state following its formation, since its re-formation by reaction with $\mathrm{H}$-Au seems unlikely. It is the strongly negative order in $\mathrm{H}_{2}$ that is least expected, as the adsorption of $\mathrm{H}_{2}$ on gold is weak [7] and under reaction conditions it is not expected to compete effectively with $\mathrm{CO}$ for adsorption on the gold surface. If however the movement of $\mathrm{H}$ atoms from $\mathrm{Ce}^{3+}$ to gold is ratedetermining, and if the $\mathrm{Ce}^{3+}-\mathrm{H}$ group is relatively stable, then the reverse process

$$
\begin{aligned}
& 2 \mathrm{Au}+\mathrm{H}_{2} \rightarrow 2 \mathrm{H}-\mathrm{Au} \\
& 2 \mathrm{H}-\mathrm{Au}^{+} 2 \mathrm{Ce}^{3+} \rightarrow 2 \mathrm{Ce}^{3+}-\mathrm{H}+2 \mathrm{Au}
\end{aligned}
$$

may also occur, so that at high $\mathrm{H}_{2}$ pressures the availability of $\mathrm{Ce}^{3+}$ sites to receive more $\mathrm{H}$ atoms will be limited, and the rate diminished. These considerations suggest that the manner of interaction of water with anion vacancies and the transfer of $\mathrm{H}$ atoms to gold particles would repay closer attention, and that the use of $\mathrm{H}_{2}+\mathrm{D}_{2}$ mixtures would inform on the extent of coverage of gold by their atoms.

The relative strengths of adsorption of $\mathrm{CO}$ and water may vary with the type of catalyst used, e.g. with the support and the gold particle size. With an $\mathrm{Au} / \mathrm{TiO}_{2}$ (mesoporous; $\mathrm{d}_{\mathrm{Au}}=4 \mathrm{~nm}, 553 \mathrm{~K}$ ) the orders are

$$
r=k P_{\mathrm{CO}}^{1.0} \mathrm{P}_{\mathrm{H}_{2} \mathrm{O}}^{0.1}
$$

i.e. the $\mathrm{CO}$ is very weakly adsorbed and the water sites are almost fully saturated [22]. 


\section{Criteria for selecting the reaction mechanism}

The relative simplicity of the reactions set using decomposition of $\mathrm{Au}-\mathrm{COOH}$ compared to that using its reaction with $\mathrm{OH}_{\mathrm{s}}$ is vividly demonstrated when the two sets are shown as catalytic cycles (see Schemes II and III); these are shown using the formalism employed previously for CO oxidation and PROX [23]. Although it would be possible for the second water molecule to be activated on the same site as the first, this is difficult to show in the cyclic format; the product water molecule in the more complex Scheme II is shown as being recycled, although it must ultimately appear as a product.

Consideration of these reaction cycles suggests a possible general principle to aid the selection of reaction mechanisms, namely, that the simplest mechanism is the most likely. Simplicity is achieved by choosing the route that involves the making and breaking of the smallest number of bonds, as the energy input needed is lower for the simpler mechanism. The merits of the most straightforward path have been invoked since William Occam deplored the unnecessary multiplication of entities in around 1300 AD; Einstein put a gloss on this when he said; "We must make things as simple as possible - but not simpler". Application of DFT is useful in identifying the route having the lowest energy barrier of those that are considered, but its success depends on making the proper choice. It sometimes seems that processes are treated that look to be improbable, while others that look better are ignored. An indication of the limits within which DFT must operate is provided by the statement [5] that it cannot treat the electronic structure of $\mathrm{CeO}_{2}$ containing anion vacancies or other defects.

\section{Comparison of the WGS with CO oxidation}

It is instructive to compare and contrast the unit steps that are proposed above for the WGS with those put forward to explain $\mathrm{CO}$ oxidation on $\mathrm{Au} / \mathrm{Al}_{2} \mathrm{O}_{3}$ [15] and on reducible oxides [12], and to

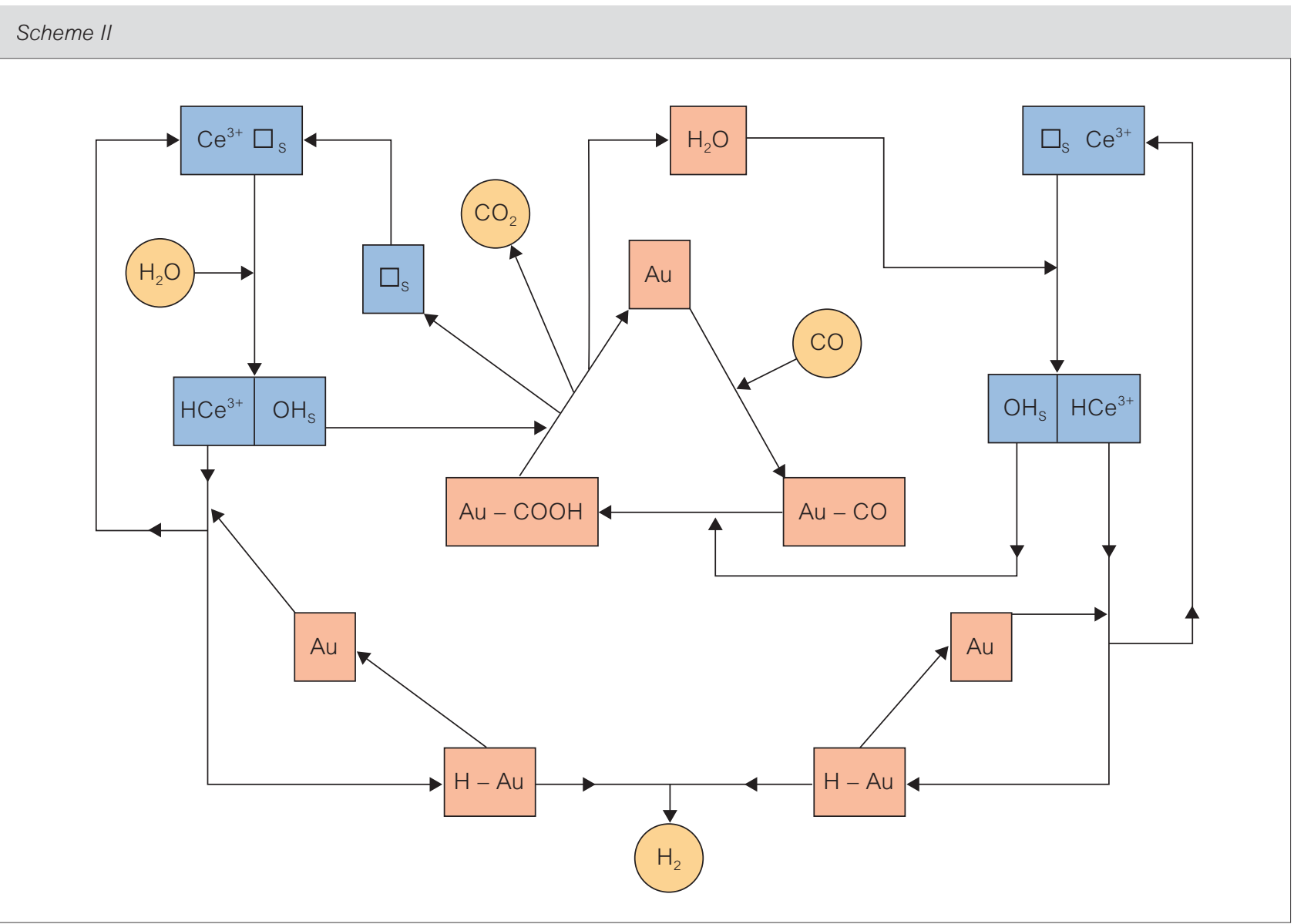

Mechanisms of the Gold - Catalysed Water-Gas Shift: Scheme II 


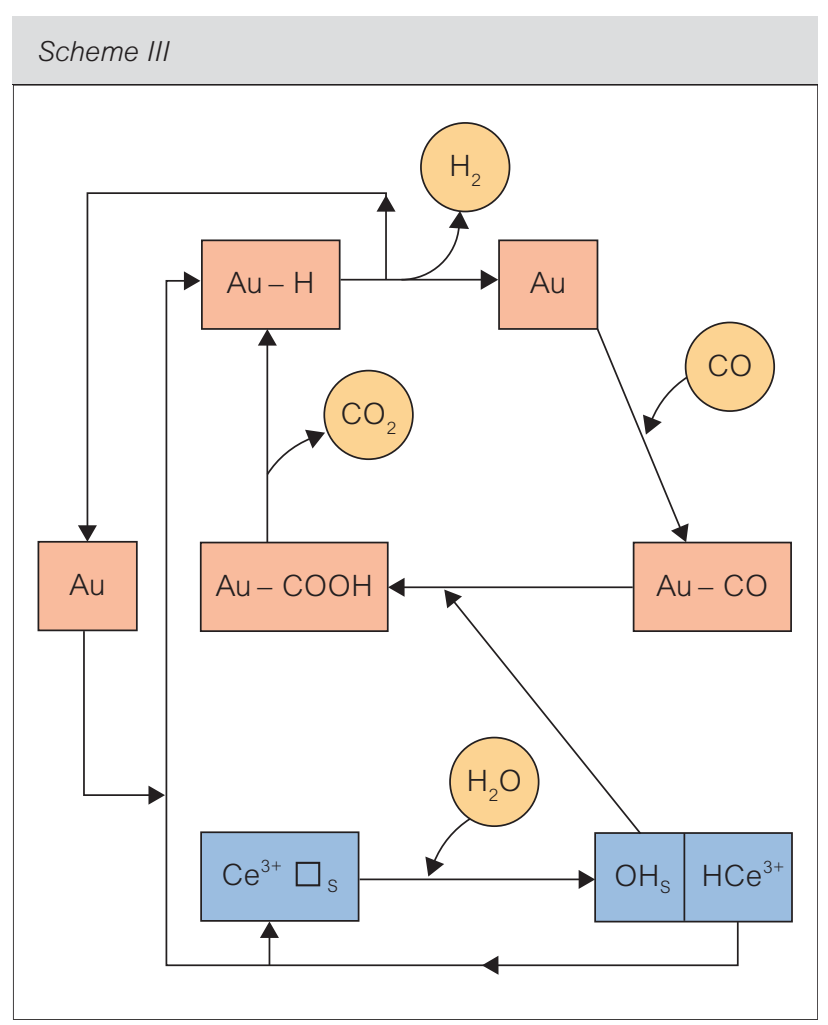

Mechanisms of the Gold - Catalysed Water-Gas Shift: scheme ///

identify the cause of the much greater activity of gold catalysts for the latter. A common feature is that the $\mathrm{CO}$ molecule is activated by reaction with an $\mathrm{OH}$ group to form (probably) an Au-COOH species; in $\mathrm{CO}$ oxidation the ready availability of $\mathrm{O}_{2}^{-}$allows its oxidation to $\mathrm{CO}_{2}$ and a peroxy group on reducible oxide supports, the latter $[1,23]$. In WGS however it has to decompose either by reaction with an $\mathrm{OH}$ species (Scheme II) or by itself (Scheme III) then oxidizing a further $\mathrm{CO}$ molecule at a necessarily higher temperature. Different roles are indicated for anion vacancies on the support, but although $\mathrm{CO}$ oxidation has been examined by gold on a great variety of oxides [12] a similarly catholic approach has not been adopted with the shift system, as such promising oxides as $\mathrm{SnO}_{2}$ and $\mathrm{V}_{2} \mathrm{O}_{5}$ have not yet received attention.

\section{Mechanisms of deactivation}

The deactivation of gold catalysts for WGS is generally attributed to a slow sintering of the gold particles [2,24], or to undesirable changes in its oxidation state or that of the support cations $[6,25]$, but other work suggests that monodentate $\mathrm{CO}_{3}{ }^{-}$is responsible, at least at high $\mathrm{CO}_{2}$ concentrations [24]; the formate species has also been implicated [26]. How $\mathrm{CO}_{3}^{-}$might be formed is unclear, but it is said to decompose at higher temperature, when the stability is greater [24]; activity is restored by oxidation [26], again implicating $\mathrm{CO}_{3}^{-}$or $\mathrm{HCO}_{2}^{-}$. The inclusion of a little $\mathrm{O}_{2}(0.5 \%)$ reduces the deactivation rate of $\mathrm{Au} / \mathrm{CeO}_{2}$ [27]; although this might inhibit formation of $\mathrm{HCO}_{2}^{-}$, which is sometimes classed as an 'unreactive spectator', it might equally well serve to maintain $\mathrm{Au}^{\delta+}$ species at the metalsupport interface, the existence of which may be necessary for the chemisorption of $\mathrm{CO}$ in a sufficiently strong state [17]. Although there are indications that very small gold particles [17], or even single atoms [4] can be active, the likely structure of particles active for WGS has not received the same attention as those performing $\mathrm{CO}$ oxidation. There the role of gold atoms at the periphery and in contact with the support, and perhaps positively charged, is often highlighted, and a clear distinction drawn between them and atoms above them. The existence of both is beneficial in $\mathrm{CO}$ oxidation, as shown by the superior activity of 'bilayer' particles; their importance in WGS is not yet established.

\section{Conclusions}

The WGS requires higher temperature than $\mathrm{CO}$ oxidation because of the difficulty of activating the water molecule and releasing its $\mathrm{H}_{2}$; anion vacancies and reduced cations on the support are needed for this. The formation of $\mathrm{CO}_{2}$ most likely occurs by thermal decomposition of a carboxyl $(-\mathrm{COOH})$ species; formic acid $(\mathrm{HCOOH})$ decomposes in a similar way, and might constitute an easy test reaction for WGS activity. The quality of simplicity is advanced as a helpful guide to selecting the most likely mechanism.

I am grateful to the late Dr David Thompson for his encouragement and assistance in the preparation of this paper.

\section{About the author}

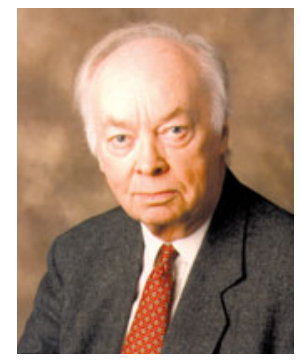

Geoffrey Bond held academic posts at Leeds and Hull Universities before joining Johnson Matthey plc in 1962 as Head of Catalysis Research. In 1970 he was appointed Professor in Brunel University Chemistry Department, and is now an Emeritus Professor at that University. 


\section{References}

1 G.C. Bond, C. Louis, D.T. Thompson, Catalysis by Gold, IC Press, London, 2006, Ch. 10

2 R. Burch, Phys. Chem. Chem. Phys. 8 (2006) 5483

3 Y. Chen, J. Cheng, P. Hu, H.F. Wang, Surf. Sci. 602 (2008) 2628

4 Q. Fu, H. Saltsburg, M. Flytzani-Stephanopoulos, Science 301 (2003) 935

5 J.A. Rodriguez, P. Liu, J. Hrbek, J. Evans, M. Pérez, Angew. Chem. Int. Edn. 46 (2007) 1329

6 Q. Fu, S. Kudriavtseva, H. Saltsburg, M. FlytzaniStephanopoulos, Chem. Eng. J. 93 (2003) 8540

7 E. Bus, J.T. Miller, J.A. van Bokhoven, J. Phys. Chem. B 109 (2005) 14581

8 G.C. Bond, Catalysis by Metals, Academic Press, London, 1962, Ch. 8

9 G.C. Bond and J.B.P. Tripathi, J. Chem. Soc. Farad. Trans. I 72 (1976) 933

10 G.C. Bond, L.R. Molloy, M.J. Fuller, J. Chem. Soc. Chem. Commun. (1975) 796

11 H. Liu, A.I. Kozlov, A.P. Kozlova, T Shido, Y. Iwasawa, Phys. Chem. Chem. Phys. 1 (1999) 2851

12 G.C. Bond, D.T. Thompson, Gold Bull. 33 (2000) 41

13 B. Schumacher, Y. Denkwitz, V. Plazak, M. Kinse, R.J. Behm, J. Catal. 224 (2004) 449

14 F.C. Meunier, A. Goguet, C. Hardacre, R. Burch, D. Thompsett, J. Catal. 252 (2007) 18
15 B.A.A. Silberova, G. Mul, M. Makkee, J.A. Moulijn, J. Catal. 243 (2006) 171

16 C.K. Costello, J.H. Yang, H.Y. Law, Y. Wang, J.N. Lin, L.D. Marks, M.D. Kung, H.H. Kung, Appl. Catal. A: Gen. 243 (2003) 55

17 Z.-P. Liu, S.J. Jenkins, D.A. King, Phys. Rev. Lett. 94 (2005) 196102

18 A.A. Gokhale, J.A. Dumesic, M. Mavrikakis, J. Am. Chem. Soc. 130 (2008) 1402

19 G.C. Bond, Catalysis by Metals, Academic Press, London, 1962, Ch. 18

20 G.J. Hutchings, J.K. Edwards, Angew. Chem. Int. Edn. 47 (2008) 9192

21 C. Padeste, N. Cant, D.L. Trimm, Catal. Lett. 18 (1993) 305

22 E.V. Rebrov, A. Berenguer-Murcia, B.F.G. Johnson, J.C. Schouten, Catal. Today 138 (2008) 210

23 G.C. Bond, D.T. Thompson, Gold Bull., accepted

24 A. Karpenko, R. Leppelt, J. Cai, V. Plzak, A. Chuvilin, U. Kaiser, R.J. Behm, J. Catal. 250 (2007) 139

25 B.A.A. Silberova, M. Makkee, J.A. Moulijn, Topics Catal. 44 (2007) 209

26 C.H. Kim, L.T. Thompson, J. Catal. 230 (2005) 66

27 W.L. Deng, M. Flytzani-Stephanopoulos, Angew. Chem. Int. Edn. 45 (2006) 2285; W. Deng, A. Frenkel, R. Si, M. FlytzaniStephanopoulos, J. Phys. Chem. C, 112 (2008) 12834 